\title{
GOVERNMENTAL POLICIES FOR ICT \\ DIFFUSION AND LEADERSHIP \\ LEGITIMACY IN GRASSROOTS \\ MOVEMENTS
}

\author{
Magda Hercheui \\ London School of Economics and Political Science, UK
}

\begin{abstract}
This empirical investigation focuses on environmental-education virtual communities and points out how the Brazilian government, through specific legislation, has increased the legitimacy of some of their members in relation to others in decision-making processes in the studied collectives. In demanding that some anchor organisations assume the formal responsibility for funded projects that aimed to diffuse Internet communication channels among environmental educators, the Brazilian government affected how community members perceived the power distribution in online collectives. Although other forces were behind the construction of legitimacy of community leaders, members broadly recognized that the law was an important factor in the construction of a common understanding on who had power in decision making. Drawing upon institutional theory, this chapter analyses how the specific legislation influenced the way community members perceived the legitimacy of their leaders. The chapter claims that policies for spreading the use of ICTs among grassroots movements and civil society organisations have direct effects in relation to their governance structures, and thus these policies should be under broader scrutiny.
\end{abstract}

Keywords: Information society, policy, ICT, social movements, institutions

\section{Introduction}

The objective of this chapter is to argue that governmental policies for the diffusion of information and communication technologies (ICTs) affect how social movements and civil society organisations perceive the legitimacy of their leaders, with consequences for their governance structure. In other words, in reinforcing the leadership legitimacy of some members in relation to others, governmental policies may favour the centralization of decision making, working against more participatory and democratic governance structures. In a broad sense, this chapter thus aims to highlight the need of reflecting on the consequences of such policies

Please use the following format when citing this chapter:

Hercheui, M., 2008, in IFIP International Federation for Information Processing, Volume 282; Social Dimensions of Information and Communication Technology Policy; Chrisanthi Avgerou, Matthew L. Smith, Peter van den Besselaar; (Boston: Springer), pp. 275-286. 
for movements whose objectives include the creation of democratic social structures.

In order to construct this argument, this chapter draws upon an empirical investigation of a group of three Brazilian environmental-education virtual communities. These three communities are informal collectives that emerged from the voluntary interaction of individuals who are concerned with the theme of environmental education. Members of the studied communities interact mainly through Internet channels, although they also cultivate face-to-face interactions.

As informal collectives, these communities cannot assume legal responsibilities, such as directly contracting governmental funding. In the beginning of the 2000s, nonetheless, these three communities received funding from the Brazilian federal government (FNMA - Fundo Nacional do Meio Ambiente). The money was given to support specific projects, mainly to allow these collectives to buy servers and computers, to organize their websites and information services, and to promote the Internet-mediated interaction among environmental educators. In exchange for the money, the communities compromised to feed a centralized federal databank with information on environmental education.

The legislation related to this funding imposed rules which were not coherent with the official governance structure of the benefited communities. In a nutshell, the legislation demanded that formal organisations (legally responsible) assume the representation of these communities in the specific projects. In order to receive the money, each community was formally represented by an anchor organisation, which was endowed with differentiated rights and obligations in relation to other members. Although the process of choosing the anchor organisations cannot be explored in this essay, it is worthy to highlight that some leaders chose them, without consulting all members.

This differentiation between formal representatives and other members clearly opposed the way these communities established their governance structures, at least rhetorically. Recalling their inherent condition as grassroots movements, these communities defended what they call the network way of organizing: when collective decisions are necessary, such as organizing a public demonstration against the government or a corporation, the final decisions should be grounded in the consensus among all members.

Community members revealed that this alleged network model is inspired by ideals of participatory democracy, in which all members would have the same rights in decision-making processes $[13,22,30]$. In practice, however, the studied communities did not adopt such a network way of organizing. The empirical investigation revealed that the communities had a centralized decision-making process, even before the introduction of the specific legislation (in the beginning of the 2000s). In other words, the studied communities cultivated, in parallel, two paradoxical governance structures: one idealized model of network, horizontal decision making, and another model of centralized decision making, in which few 
members (called here "leaders") make decisions in name of the community, excluding "ordinary" members.

This paper takes for granted this situation of contradictory and parallel models of decision making, and examines how the specific legislation has interfered in the way members perceived the legitimacy of leaders in these communities, supporting the centralization of governance structures. Other forces and mechanisms have also influenced the legitimacy of community leaders, but for lack of space this paper focuses only on the role of the specific legislation in this process.

The concept of legitimacy in this paper draws upon institutional theory. As summarized by Suchman [31], legitimacy is the perception (or assumption) that specific actions are appropriate within a social system of norms, values, and beliefs, which implies that legitimate actions are understood as natural and meaningful. In a more systematic fashion, Scott [26] argues that legitimacy depends on conformity to formal rules, to moral bases, and to taken-for-granted frames of reference. The author adds that in modern societies authorities such as the government have the role of conferring legitimacy [26]. This chapter focuses on discussing how the governmental action and the conformity to rules reinforce the legitimacy of community leaders as community representatives, thus undermining the relevance of other members as leaders.

The next sessions develop this argument. Session 1 presents the empirical objects and methodology of this research. Session 2 summarizes the main findings of the empirical study. Session 3 discusses the findings through the lens of institutional theory, arguing that the government, through creating legislation, has influenced the way community members perceive the legitimacy of their leaders. Finally, session 4 concludes, reflecting on the need of having awareness of the impact of governmental projects to diffuse ICTs among civil society and grassroots movements.

\section{Empirical object and methodology}

In the academic literature, the term virtual community (and similar ones such as online communities and virtual or online social networks) is used generically to describe collectives which emerge from voluntary computer-mediated interaction $[2,3,23,30]$. More restrictedly, Graham [10] defends the use of the term only for those Internet-mediated collectivities that have (i) voluntary membership of people who have (ii) common interests and (iii) adhere to a set of rules (such as procedures for admission and exclusion). This investigation adopts this more restricted meaning of virtual community, as the studied communities have these three characteristics.

This research investigates three Brazilian environmental-education virtual communities:

Rebea (Rede Brasileira de Educação Ambiental) (Brazilian EnvironmentalEducation Network): created in 1992 and active at a national level. The 
community had around 380 members (membership numbers in the three communities are related to 2006) on the general discussion list and around 600 members on Orkut - the Google's online social network (some members are in both lists). Website: http://www.rebea.org.br .

Repea (Rede Paulista de Educação Ambiental) (São Paulo EnvironmentalEducation Network): created in 1992, but active more regularly since 1999, in the State of São Paulo. The community had around 560 members on the general discussion list. Website: http://www.repea.org.br/.

Reasul (Rede Sul Brasileira de Educação Ambiental) (Brazilian SouthRegion Environmental-Education Network): created in 2002 and active in three states of the Brazilian south (Rio Grande do Sul, Santa Catarina and Paraná). The community had around 2,000 members on the general list. Website: http://www.reasul.org.br/mambo/.

Although the communities have received financial and material support from formal organisations (governmental offices, universities, and non-governmental organisations), their members understood that these communities are independent social movements (called networks), because their links with organisations are informal and membership is voluntary.

The main stated goal of these communities is to organize the diffusion of information and knowledge, to debate technical and political issues related to the field of environmental education, and to mobilize their members to collective action in order to influence the government, other institutions, and private organisations. Their main communication channels are the discussion lists (such as Yahoo! and Google), through which members receive and send messages daily.

In order to investigate how the specific legislation affected the legitimacy of community leaders (research question), this research adopted a qualitative methodology (in-depth, semi-structured interviews), grounded in an interpretive approach. The interpretive perspective understands that social research may investigate phenomena through uncovering the inter-subjective meanings social actors attribute to them $[9,11]$. Community members are thus the primary source of data $[12,18]$. A total of 43 in-depth interviews were conducted, between April and June 2006. The selection of interviewees was done by a snowball process [7]: key informants (listed in the communities' websites) were first contacted and they indicated other members.

In spite of the inherent ambiguities of qualitative research $[1,11,14]$, this study adopted a rigourous set of criteria to elaborate a coding process which permitted the construction of an understanding which is convincing and logically consistent $[1,9]$. The research obtained a great level of agreement among respondents, which is an indicator of reliability in qualitative research [18, 21, 32]. The findings are combined here into a singular case, as this paper does not have space for conducting a multiple-case study in details.

Furthermore, the findings are consistent with institutional theory (see session $3)$, which is also an indicator of rigour in qualitative research [6, 21]. Indeed, institutional theory has been chosen as an adequate lens for understanding the 
studied phenomenon because it provides a consistent framework on how institutions influence legitimacy and how legitimacy support institutions [26, 27, 31]. The coding process started from the institutional framework, in a deductive fashion. The interaction with data, however, has improved the original coding, in an inductive fashion. Thus, the final result presented in this article is the consolidation of a coding process which has elements of deduction (theory structuring coding) and induction (codes emerging from the data).

The original interviews were in Portuguese and were translated into English by the researcher. The presented transcriptions respect the original meaning, but some editing has been done, avoiding expressions and digressions which do not help the understanding of the discourse $[8,16,24]$. The interviewees are identified by the name of their communities (Rebea, Repea, and Reasul) and a number created at random to preserve the anonymity of respondents.

\section{Main findings}

Members of the three studied communities highlighted the relevance of the governmental funding (FNMA) for their collectives in terms of empowering the communities. With this funding, these communities bought servers, produced their websites (improving their visibility to the general public), and contracted professionals to organize and feed information into their communication channels (mainly the discussion lists and websites). As summarized by a Rebea 1:

The FNMA funding mobilized the communities and permitted things to work better. Because of this money, the communities achieved a higher level in their activities. It was a partnership between communities and the government, with common objectives.

Also Rebea 2 agreed:

The governmental funding permitted the community to organize itself, to construct a website and to contract a professional in communication [to support community activities]. These improvements were not coming through voluntary work.

Members of the three communities emphasized, nonetheless, that the funding was grounded in a specific legislation, which forced the communities to be represented in the contracts by formal organisations. Recall that these communities do not have a formal, legal existence, thus they could not be accountable for public contracts.

In order to overcome this obstacle, the government created an intermediary solution: the communities could keep their informality, as far as one formal organisation (called an "anchor") could assume the responsibility in name of the community. In other words, these formal organisations would sign up contracts, receive the money, and be accountable for both the use of the funding and the contractual commitments (mainly the feeding of the federal databank). These formal organisations could be prosecuted by the government if the contracts were not respected. As explained by Repea 1: 
The legislation imposed the conditions to provide funding. The community [through the anchor organisation] accepted the governmental demands: one formal organisation should represent the community.

Also Rebea 5 argued in the same direction:

It is a legal impasse: the government cannot give money to informal communities. Someone should be accountable for the money. If individuals had received money directly in their personal bank accounts, which would be the priorities?

The governmental concern about accountability appeared to be broader than the distinction between informal communities versus formal anchor organisations. As explained by Rebea 14, the government would not have accepted a non-relevant organisation as a representative of the communities:

The government wanted a "good" formal organisation [to represent the community in the project]. One small non-governmental organisation would not be acceptable as a representative [although this is not a formal rule, the member argued it was a known norm].

This is also the opinion of Repea 4:

The anchor organisation should have the structure to face the legal demands. The received money would not be enough if the organisation did not have its own structure working.

Consequently, these formal organisations that were responsible for the contracts either obtained a leadership role in these communities or reinforced their previous leadership. Indeed, although these communities emphasized that all members have equal rights and power in their collectives, members recognized that the legislation favoured a more centralized perception of their governance structure. Rebea 2 summarizes:

This is the drama with civil society organisations: the work is directed by the ones who fund the collectives. The problem is not to receive money from the government, but to balance whether community members have capacity to negotiate with the government about how the money would be expended.

The common understanding of members was that the only way of obtaining the governmental funding was to accept this rule of being represented formally by an anchor organisation. In other words, members legitimated the acceptance of an organisational structure mediated by formal organisations because they believed the funding would benefit the whole community. As defended by Repea 2:

Without the governmental money, the things happen in a slow way in the communities. When we had the FNMA project, we had goals.

Without the funding, the process was free, without planning.

Members linked with the anchor organisations were endowed with differentiated rights (they received the money and had legal power to decide about the projects) and obligations (they needed to guarantee that resources have been used correctly) in relation to other members. The contracts were enforced by the 
specific and general legislations: the government could use coercive mechanisms to force the anchor organisations to fulfil the contract. Consequently, the legislation favoured the centralization of decision making because only the anchor organisation would face coercive sanctions if the contract was not fulfilled, argued Repea 9. The same reasoning is formulated by Repea 5:

Some discussions should be restricted to a group of people in order to not damage the project. The organisation which received the money for the project was selected to make decisions in the way it wanted. It would not be possible to discuss the project with the whole community. Those organisations which asked the money should manage the project.

Other community members argued in the same direction:

We cannot put 600 people discussing a project. We discuss among few leaders, because one organisation is accountable for the money [Repea 8].

In the FNMA, people were accountable for the money. If the person is not legally responsible, she will not commit. People may contribute, but not in the way it is demanded formally [considering the contract] [Reasul 10].

Interestingly, this legislation could only affect the governance structures of the projects ruled by the specific contracts. In other words, the government demanded an anchor organisation to respond for specific funding, not for the community as a whole. As stated by Reasul 9:

The FNMA demanded a coordinator for the funded projects, not for the communities [as a whole], but the group which managed the projects extended their attributions to manage other community issues.

Thus, the community could keep parallel structures of governance, as far as the one responsible for the funding followed the legal imposition of having a formal representative. Furthermore, the legislation did not impose any rule in relation to how decisions should be made even in the funded projects. In other words, the legislation imposed accountability for anchor organisations, but it did not imply necessarily that these organisations should make decisions in a more centralized or decentralized way. Although respondents identified that the legislation had limited scope in terms of interfering in the way communities make decisions, the leadership of the anchor organisation in decision making related to other issues was accepted as legitimate.

In practice, using the argument that the legislation imposed a more centralized governance structure, interviewees legitimated the leadership of members who were linked to the anchor organisation. Members of the anchor organisations, for instance, argued that they would not be able to fulfil the contracts, considering the complexity of tasks and bureaucratic procedures, if they had not centralized the 
decision making. As explained by Repea 1, representative of the anchor organisation:

The accountability was very detailed, demanding receipts and public scrutiny in the contracting of people. It was a lot of work, which really overwhelmed the anchor organisation. This legislation forced the community to differentiate between the anchor organisation's members and the other members.

Also Reasul 1, representative of the anchor organisation, confirmed:

The money was managed by the anchor organisation, which reduced the autonomy of other members. The boundaries of the FNMA project and the community as a whole become blurred, because we [the anchor organisation] had deadlines and formal goals [which was not the case for the members who were not affiliated to the anchor organisation].

Furthermore, the interviewees also called attention to the fact that even after the end of the funding projects, the anchor organisations in the three communities kept their relative leadership, at least for a while. As the representative of an anchor organisation (Repea 1) explained:

The money had finished, but not the work. We continued to work, and people understood that our organisation [anchor] kept the leadership of the community. Although we formally are not anymore the executive secretary, I do not know if people acknowledge this change, as we keep answering the telephone and the emails [as community representatives].

This impression is confirmed by Repea 3:

In my opinion, after the project, the very same people [representatives of the anchor organisation] kept going as executive secretaries, although now they call themselves management group.

\section{Discussion}

In this part, this chapter discusses the findings considering the insights provided by institutional theory [5, 26, 27]. In sum, the findings point to the conclusions that the discussed legislation (FNMA funding) has reinforced the legitimacy of specific leaders, related to the anchor organisations, through two sanction mechanisms: the recognition of legitimate authority (rewarded by the funding) and the possibility of imposing punishment (in the case of contractual breaking). These claims are developed below.

As defined by Scott [26, p. 48]: "Institutions are social structures that have attained a high degree of resilience [...] [which] are composed of culturecognitive, normative, and regulative elements, that, together with associate activities and resources, provide stability and meaning to social life."

Considering the scope of this paper, there are two aspects of this definition that should be explored. First, Scott claims that institutions are resilient social 
structures. In this specific study, the legislation favours the reproduction of a very traditional social structure - the centralization of decision making. Indeed, this is a governance social structure which is pervasive in hierarchical organisations [29]. In other words, the studied legislation formalised instruments which could influence the communities in adopting a centralized decision-making model, in spite of their intentions (at least in the rhetorical level) of cultivating network governance structures.

Second, Scott [26] proposes the idea that institutions are composed of different sort of elements. In the studied case, the regulative element is the main focus of interest, as the legislation fostered centralized decision making through coercive mechanisms: if something went wrong, the anchor organisation would be legally accountable. Although the legislation imposed only an accountability structure rather than a decision-making one, members in general legitimated the empowerment of the anchor organisations as they were the ones which risked suffering punishment. In this example, the coercive mechanisms favoured the diffusion of centralized decision-making structures $[5,26]$.

Clearly, members recognized the logic of instrumentality, brought by the legislation, as proposed by Scott [28]. In other words, the legislation is interpreted as having legitimate means (enforcement mechanisms and centralization of decision making) and ends (beneficiating the communities with funding). In regulative systems, the basis for legitimacy is legally sanctioned [28].

In legitimating centralized decision-making models, which are mainly managed by the anchor organisations, the legislation has facilitated the institutionalization the diffusion of social structures through settings in time and space [25, 26] - of hierarchical governance models in informal communities. In addition, these centralized models have affected the perception of community members of the legitimacy of the leadership of individuals who were associated with the anchor organisations.

As explained by DiMaggio and Powell [5], coercive mechanisms are supported by formal and informal pressures, from the legal environment to the political influence, including persuasion and even cultural expectations. The authors argue, for instance, that the objective of obtaining funding from hierarchical institutions is an obstacle to any organisation creating a more egalitarian governance form [5]. Indeed, the findings support this idea: many members have accepted the reproduction of hierarchical structures as a mean of obtaining funding in spite of their rhetoric of nurturing horizontal, network forms of organizing.

The findings also support the idea that the communities adopted hierarchical structures in order to improve their legitimacy in society, as proposed by Meyer and Rowan [20] and Meyer [19]. More specifically, they adopted centralized decision making in order to legitimate themselves and their leaders as accountable actors. At a more normative level, the centralization of decision making in the hands of legitimate leaders is considered appropriate within the specific set of values and beliefs $[17,26,31]$, i.e., the perception that it would be acceptable to 
recognize the legitimate authority of the anchor organisations in order to receive governmental funding, as expressed by respondents.

Furthermore, the process of institutionalization is not static. As soon as some members are legitimate as leaders, they have further possibilities of controlling the methods of enforcement to foster the reproduction of centralized decision-making model $[15,25]$. Indeed, the findings echo this institutional perspective: some leaders were benefiting from the described perception of legitimacy even after the end of the funded projects, as they kept themselves in strategic positions in the communities' governance structures.

\section{Conclusion}

Interpreting the empirical findings, this paper concludes that the Brazilian government, through specific policy, has affected the way members of the studied environmental-education virtual communities perceived the legitimacy of their leaders. Although the legislation itself has not impose rules of governance for the community as a whole, the fact that the government established a contractual relationship with some community representatives (anchor organisations) rather than with others (or the community as a whole) has affected the perception of legitimacy of these representatives. The very simple fact that the government cultivates interactions with some members instead of others affects the perception of who is a legitimate leader.

The findings show that the funding legislation affected the legitimate authority of some community leaders through sanctions mechanisms. On the one hand, the communities accepted the legal impositions in order to qualify for receiving governmental money (reward mechanism). On the other hand, the communities altered their perception of legitimate governance structures through recognizing the fact that the anchor organisations were the ones taking the risk (punishment mechanism). Furthermore, the communities kept legitimating the leadership of the anchor organisations even after the end of contracts, which calls attention to the inertial forces present in process of institutionalisation.

Considering the concern related to policies, the findings contribute to the discussion on the diffusion of ICTs and democracy. Many have claimed that the organisation of grassroots movements and civil society organisations through computer-mediated channels would empower these collectives [2, 3, 4, 10, 23], permitting more participatory, democratic decision-making processes $[13,22,23$, 30].

The findings, however, to some extent challenge these arguments. First, the interviewees revealed that the communities committed rhetorically with a network, participatory decision-making model meanwhile in practice they cultivated other governance structures. Second, the findings showed that in some circumstances grassroots movements may be inclined to accept new rules in order to receive direct and indirect incentives, such as funding. Third, the data indicated how a specific legislation which aimed to diffuse the appropriation of ICTs 
through communities of environmental educators has affected the way these collectives perceive the legitimacy of their leaders, reinforcing centralized governance structures.

To be clear, these communities did not already have an effective network organisation and for this reason it is not possible to say that the legislation has changed the governance structures of these communities. Members did express, however, that the legislation has reinforced the legitimacy of some community leaders. Although other factors have also influenced the distribution of power among members, the fact that the government legitimated some leaders rather than others has been recognized as an important fact in the definition of who is more central in the process of making decisions.

In conclusion, this chapter claims that although ICTs may be related to processes of cultivating more democratic and participatory decision-making in society, it is important to be attentive to the way traditional social structures influence the new forms of interacting through computer-mediated channels. Naturally, this paper does not deny the relevance of ICTs to the empowerment of grassroots movements and civil society organisations; rather, it calls attention to the need to be aware of how institutional forces in society may influence the kind of interactions in virtual collectives. In observing how policies related to ICTs affect in practice the governance structures of grassroots movements, citizens may organize themselves to favour regulations which do not go against the interests of the democratic aspirations of these collectives.

\section{References}

[1] Bauman, Z. (1978). Hermeneutics and social science - approaches to understanding. London: Hutchinson of London.

[2] Castells, M. (1996). The rise of the network society. Massachusetts; Oxford: Blackwell Publishers.

[3] Castells, M. (2001). The internet galaxy: Reflections on the internet, business and society. Oxford; New York: Oxford University Press.

[4] Delanty, G. (2003). Community. London; New York: Routledge.

[5] DiMaggio, P.J. \&Powell, W.W. (1991 [1983]). The iron cage revisited: Institutional isomorphism and collective rationality in organizational fields. In W.W. Powell and P.J. DiMaggio (Eds.), The new institutionalism in organizational analysis. Chicago; London: The University of Chicago Press.

[6] Eisenhardt, K.M. (1989). Building theories from case study research. The Academic of Management Review, 14(4), 532-550.

[7] Esterberg, K.G. (2002). Qualitative methods in social research. Boston: McGrawHill.

[8] Flick, U. (2002). An introduction to qualitative research ( $2^{\text {nd }}$ edition). Thousand Oaks; London; New Delhi: Sage Publications.

[9] Gadamer, H. (1989 [1975]). Truth and method. (2 ${ }^{\text {nd }}$ revised edition). London: Sheed \& Ward.

[10] Graham, G. (1999). The internet: A philosophical inquiry. London: Routledge.

[11] Habermas, J. (1981 [1968]). Knowledge and human interests. London: Heinemann. 
[12] Hakim, C. (2000). Research design - successful designs for social and economic research ( $2^{\text {nd }}$ edition). London; New York: Routledge.

[13] Juris, J.S. (2005). The new digital media and activist networking within anticorporate globalization movements. Annals, AAPSS, 597, 189-208.

[14] Klein, H.K. \& Myers, M.D. (1999). A set of principles for conducting and evaluating interpretive field studies in information systems. MIS Quarterly, 23(1), 67-94.

[15] Knight, J., and Ensminger, J. (1998). Conflict over changing social norms: Bargaining, ideology and enforcement. In M.C. Brinton and V. Nee (Eds.), The new institutionalism in sociology. Stanford, CA: Stanford University Press.

[16] Kvale, S. (1996). InterViews: An introduction to qualitative research interviewing. Thousand Oaks; London; New Delhi: Sage Publications.

[17] March, J.G. (1994). A primer on decision making: How decisions happen. New York: The Free Press; London: Maxwell Macmillan International.

[18] Mason, J. (2002). Qualitative researching ( $2^{\text {nd }}$ edition). London; Thousands Oaks; New Delhi: Sage Publications.

[19] Meyer, J.W. (1994). Rationalized environments. In W.R. Scott and J.W. Meyer (Eds.), Institutional environments and organizations. Thousands Oaks; London; New Delhi: Sage Publications.

[20] Meyer, J.W., and Rowan, B. (1977). Institutionalised organizations: Formal structures and myth and ceremony. The American Journal of Sociology, 83(2), 340-363.

[21] Patton, M.Q. (2002). Qualitative research \& evaluation methods ( ${ }^{\text {rd }}$ edition). Thousand Oaks; London; New Delhi: Sage Publications.

[22] Pickard, V.W. (2006). United yet autonomous: Indymedia and the struggle to sustain a radical democratic network. Media, Culture \& Society, 28(3), 315-336.

[23] Rheingold, H. (2000 [1993]). The virtual community: Homesteading on the electronic frontier (revised edition). Cambridge, MA: MIT Press.

[24] Rubin, H.J., and Rubin, I.S. (2005). Qualitative interviewing - the art of hearing data ( $2^{\text {nd }}$ edition). Thousand Oaks; London; New Delhi: Sage Publications.

[25] Scott, W.R. (1998). Organizations: rational, natural and open systems (4 ${ }^{\text {th }}$ edition). Upper Saddle River, NJ: Prentice Hall International.

[26] Scott, W.R. (2001). Institutions and organizations ( $2^{\text {nd }}$ edition). Thousand Oaks; London; New Delhi: Sage Publications.

[27] Scott, W.R. (2003). Institutional carriers: Reviewing modes of transporting ideas over time and space and considering their consequences. Industrial and Corporate Change, 12(4), 879-894.

[28] Scott, W.R. (2005). Institutional theory: Contributing to a theoretical research program. In K.G. Smith and M.A. Hitt (Eds.), Great minds in management: the process of theory development. Oxford: Oxford University Press.

[29] Simon, H. (1997 [1945]). Administrative behaviour: A study of decision-making processes in administrative organization ( $4^{\text {th }}$ edition). New York: Free Press.

[30] Steinmueller, W.E. (2002). Virtual communities and the new economy. In R. Mansell (ed.), Inside the communication revolution - evolving patterns of social and technical interaction. Oxford: Oxford University Press.

[31] Suchman, M.C. (1995). Managing legitimacy: Strategic and institutional approaches. Academy of Management Review, 20(3), 571-610.

[32] Yin, R.K. (2003). Case study research: design and methods ( $3^{\text {rd }}$ edition). Thousand Oaks; London; New Delhi: Sage Publications. 